\title{
Impact of pasture height and herbage mass on suppression of variegated thistle in North Island East Coast hill country
}

\author{
Katherine N. TOZER ${ }^{1 *}$, Rose GREENFIELD ${ }^{1}$, Renee GRIGSON ${ }^{1}$, Catherine CAMERON ${ }^{1}$, \\ Ants ROBERTS ${ }^{3}$, Emma NOAKES ${ }^{2}$, Tim RHODES ${ }^{4}$ and Sue ZYDENBOS ${ }^{5}$ \\ ${ }^{1}$ AgResearch, 10 Bisley Rd, Hamilton 3214, New Zealand \\ ${ }^{2}$ AgResearch, 11 Dairy Farm Rd, Palmerston North 4442, New Zealand \\ ${ }^{3}$ Ravensdown Ltd, 292 Main South Road, Christchurch 8042, New Zealand \\ ${ }^{4}$ Wi Pere Trust, Lavenham Rd, Gisborne 4071, New Zealand \\ ${ }^{5}$ AgResearch, 1365 Springs Rd, Lincoln 7674, New Zealand \\ *Corresponding author: Katherine.tozer@agresearch.co.nz
}

\begin{abstract}
Variegated thistle in East Coast North Island hill country reduces pasture and livestock productivity. To quantify the impact of increasing amounts of pasture cover (herbage mass) on this weed, variegated thistle seeds were hand-sown in autumn into pasture swards that ranged in height from $0 \mathrm{~cm}$ (bare ground) to $12 \mathrm{~cm}$, on an East Coast property near Gisborne. Sward height was maintained by mowing without damaging the thistle plants. Increasing pasture cover reduced thistle emergence, height, diameter, biomass, survival and seed production. By early June, 7 weeks after sowing, thistle emergence was greatest from bare ground and from maintaining a pasture height of $3 \mathrm{~cm}\left(>1100 \mathrm{~kg} \mathrm{DM} \mathrm{ha}^{-1}\right.$ in autumn) and declined with increasing pasture height. By December, thistle height, diameter, biomass, flowerhead production and survival were highest in the bare ground treatment (thistle biomass $\approx 760 \mathrm{~g} \mathrm{plant}^{-1}$ ), much lower in the 3 -cm pasture height treatment $\left(\approx 20\right.$ g plant $\left.^{-1}\right)$, negligible in the $6-\mathrm{cm}(>1600 \mathrm{~kg} \mathrm{DM} / \mathrm{ha})$ and nil in the $8-\mathrm{cm}$ $\left(>1800 \mathrm{~kg} \mathrm{DM} \mathrm{ha}{ }^{-1}\right)$ and $12-\mathrm{cm}\left(>2700 \mathrm{~kg} \mathrm{DM} \mathrm{ha}{ }^{-1}\right)$ pasture treatments $(\mathrm{P}<0.002)$. Maintaining pasture height of $3 \mathrm{~cm}$ severely reduced variegated thistle establishment, growth and flowerhead production. Results infer that grazing management strategies, such as lengthening the interval between grazing events in autumn and early winter, will increase pasture cover and are likely to severely reduce thistle establishment, growth and seed production.
\end{abstract}

Keywords: grazing strategy, revegetation, weed management

\section{Introduction}

Variegated thistle (Silybum marianum Gaertn.) is prevalent in East Coast North Island hill country. It causes severe production losses of desired species by shading and replacing pasture. Variegated thistle infestation reduced farm profitability on one large property near Gisborne by 37\% ( $\left.\$ 135 \mathrm{ha}^{-1}\right)$, because of its negative impact on pasture production, stocking rate and the potential to finish lambs in summer (Stevens et al. 2019).

Variegated thistle is an annual or biennial that mainly germinates in autumn. It produces a rosette that expands rapidly during late autumn and winter and then the stem elongates in the following spring to produce multiple branches and flowerheads up to $2 \mathrm{~m}$ high (Khan et al. 2009). The plant senesces as summer progresses, and the seeds mature and are dispersed near the parent plant. Large areas of bare ground can be created by the death of variegated thistle plants, which can be reinfested through establishment of thistle seedlings from the seedbank in autumn (James \& Tozer 2018).

Control of variegated thistle on New Zealand farms has relied heavily on aerial or ground application of herbicides in early spring (September). Many of the herbicides required to kill the large thistle rosettes in early spring also damage valuable legumes. Focusing on precision application of 'clover-friendly' herbicides in early autumn rather than the more typical blanket spraying in early spring is a recommended alternative (Tozer et al. 2018). However, alternative control methods are required due to increasing consumer demand for herbicide-free farming (Finger 2018) and the increasing risk of herbicide resistance (Bourdôt et al. 2007; Heap 2014).

Goats readily graze variegated thistle (Harrington et al. 2011; Greenfield et al. 2019) but there are difficulties in containing goats. Also, there is a limited value chain for goat products, which explains in part why they are not used widely by New Zealand farmers for weed control (Scholtens et al. 2017). Oversowing competitive pasture species into bare areas created by the death of variegated thistle thickets to prevent establishment of emerging thistle seedlings is also problematic in New Zealand hill country. Stock tend to preferentially graze the more palatable oversown species in unimproved hill country pastures, which are typically dominated by browntop (Agrostis capillaris L.) and other weedy grasses (Tozer et al. 2018). Variegated thistle seedlings are large and likely to outcompete other seedlings that have been oversown in the bare areas (James \& Tozer 
2018). In New South Wales, Australia, the deep-rooted perennial species lucerne (Medicago sativa L.) and phalaris (Phalaris aquatica L.) were shown to exclude variegated thistle when sown into cultivated plots, while the annual species, Wimmera ryegrass (Lolium rigidum Gaud.) and subterranean clover (Trifolium subterraneum L.) did not (Michael 1968). Neither of the perennial species lend themselves to successful oversowing in uncultivatable New Zealand hill country.

Another approach to creating a competitive pasture sward is to increase the pasture cover (herbage mass) in summer/early autumn prior to the germination of thistle seeds. This strategy focuses on the pasture canopy shading emerging thistle seedlings and preventing their establishment, as has occurred when Californian thistle (Cirsium arvense L. Scop.) seedlings were transplanted into dense pasture swards in a pot study (Bourdôt et al. 2015). The impact of pasture cover on variegated thistle establishment in glasshouse studies was investigated by Pook (1983) and Phung and Popay (1981), who found that increasing levels of shade (Pook 1983) and taller pastures (Phung \& Popay 1981) severely reduced the growth of thistle seedlings. However, it is not known what pasture height or biomass is required to suppress variegated thistle establishment and growth in the field and for how long it must be maintained in a North Island East Coast hill country environment.

To investigate the impact of increasing levels of pasture cover on variegated thistle establishment and growth, a replicated mown field study was established on an East Coast property near Gisborne in autumn 2019. We hypothesised that thistle seedling establishment in autumn would be increasingly suppressed as sown pasture sward height and mass increased and that high covers would be required throughout autumn for thistle seedling densities to be severely reduced.

\section{Methods}

\section{Experimental site}

A site was established on the Wi Pere Tangihanga

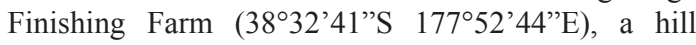
-country beef and sheep property west of Gisborne, on a Taupo tephra (pumice) soil over mudstone with a sandy silt loam texture. The site was on an old perennial ryegrass (Lolium perenne L.) based pasture, with a north-westerly aspect, a slope angle of $\approx 8^{\circ}$ and a maritime climate with rainfall distributed fairly evenly during the year (Figure 1).

At the time of establishment, 30 snip samples were randomly collected from the site, transported chilled to the laboratory, dissected into components and oven dried at $64^{\circ} \mathrm{C}$ to a constant weight to determine the contribution of the different components to total dry matter. The pasture was dominated by perennial ryegrass $(31 \%$ of total $\mathrm{DM})$, and included other grasses

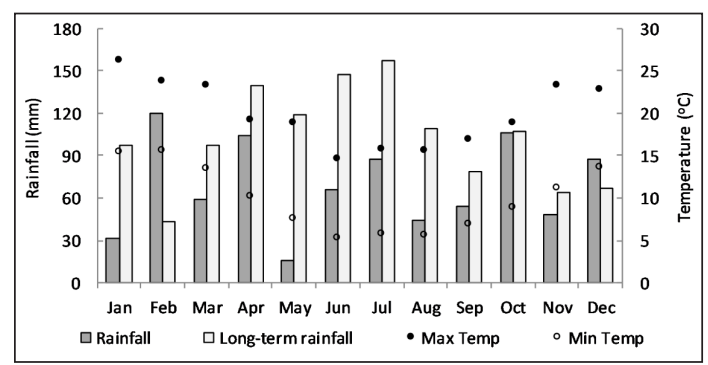

Figure 1 Monthly rainfall in 2019 , average monthly longterm rainfall (2005-2014) $\ldots$, and average monthly maximum • and minimum $O$ temperatures in 2019 for the experimental site. Data are from the NIWA Virtual Climate Station (https://niwa.co.nz/climate/ our-services).

such as browntop and sweet vernal (Anthoxanthum odoratum L.; 19\%), white clover (T. repens, 15\%), broadleaf weedy species (3\%) and dead matter (32\%). There was negligible bare ground.

A wire-netting fence with an electric top-wire was erected to exclude livestock in mid-March 2019. On 28 March 2019, the pasture was mown to $\approx 10 \mathrm{~cm}$ with a weed eater, which corresponded to an average pasture cover of $1900 \mathrm{~kg} \mathrm{DM} \mathrm{ha}^{-1}$ averaged over all plots. The estimate was obtained using a Rising Plater Meter (EC10 Jenquip, Feilding, NZ; 10 random positions per plot).

\section{Experimental design and treatments}

Treatments comprised five sward heights into which variegated thistle seeds were hand sown: $0 \mathrm{~cm}$ (bare ground), $3 \mathrm{~cm}, 6 \mathrm{~cm}, 8 \mathrm{~cm}$ and $12 \mathrm{~cm}$. They were arranged in a Latin square design, with five replicates of each treatment. Plot size was $2.0 \times 3.5 \mathrm{~m}$, with $0.5 \mathrm{~m}$ buffers between all plots. The bare ground treatment was created by application of Glyphosate 360 (Ravensdown Ltd, NZ; $25 \mathrm{~mL}$ in $15 \mathrm{~L}$ water) using a knapsack, on 4 April 2019. A mower was used to create the $3-\mathrm{cm}$, 6-cm and 8-cm height treatments, and a weed eater the 12-cm height treatment, on 19 April 2019.

Mature variegated thistle seeds were collected during summer 2018-2019 from the Tangihanga Finishing Farm. To determine their germination percentage, 8 replicates of 50 variegated thistle seeds were placed at equi-distances within a folded damp paper towel, enclosed in a snap-lock bag and maintained at a constant temperature of $25^{\circ} \mathrm{C}$ for 4 months (November 2018-March 2019). A total of $95 \%$ of variegated seeds germinated. On 19 April 2019, a single thistle seed was hand sown at a depth of $5 \mathrm{~mm}$ at $70-\mathrm{cm}$ intervals along each of three parallel transects separated by $60 \mathrm{~cm}$ in each plot ( $\mathrm{n}=15$ sowing positions). Slug bait pellets ( $15 \mathrm{~g} \mathrm{~kg} \mathrm{~g}^{-1}$ metaldehyde) were applied at a rate of $400 \mathrm{~g}$ per plot $\left(57 \mathrm{~g} \mathrm{~m}^{-2}\right)$ at the time of sowing thistle seeds. 


\section{Site management}

Plots were mown to their designated treatment height using the mower ( $0 \mathrm{~cm}$ (bare ground), $3 \mathrm{~cm}, 6 \mathrm{~cm}$ and 8 $\mathrm{cm})$ or weed eater $(12 \mathrm{~cm})$. Scissors or hedge trimmers were used to defoliate the pasture to the designated height in the vicinity of the variegated thistle plant to ensure that treatment heights were maintained but that thistle plants were not damaged. Mowing occurred at approximately 12-day intervals on: 23 May; 7, 17 and 28 June; 9, 22 and 31 July; 12 and 27 August; 12 and 23 September; 10 and 21 October; 4, 15 and 26 November and 5 December. Large broad-leaved weeds in the bare-ground treatment were handweeded. When the thistle plants became reproductive, buds (i.e. flowerheads without any petals visible) were left intact but flowers (i.e. with purple petals visible) were decapitated after being counted. Flowers removed during the study were autoclaved to render seed nonviable.

\section{Measurements}

Soil surface temperature (0-2.5 cm depth) and photosynthetically active radiation (PAR) at the soil surface were logged hourly using ibuttons (DS1922L-F5\# Thermochron Ibutton) and Odyssey® Submersible PAR (Photosynthetic Active Radiation) logger sensors, in one of the five replicate blocks between mid-April and the beginning of December 2019. Soil moisture to a depth of $12 \mathrm{~cm}$ was assessed in April, May, June, July, September and December using a calibrated TDR (Time Domain Reflectrometry) probe (TDR HS2 HydroSense II w/ CS659 12-cm sensor).

Presence, standing height, and diameter of the rosette at the widest point was assessed for each thistle plant prior to mowing. Pasture mass was assessed using a Rising Plater Meter (Jenquip EC10; 10 random positions per plot).

On 5 December 2019, plants were destructively harvested. The number of buds and flowers on each plant were recorded. The number of buds and flowers from the final harvest and those that had been previously removed were summed to calculate the total number of flowerheads per plant.

Variegated thistle plants were removed at ground level using secateurs for smaller thistle and machetes for large thistle plants. Small thistle plants were weighed, transported to the lab and oven dried at $64^{\circ} \mathrm{C}$ for five days and reweighed. Larger thistle plants (from the bare ground treatment) were weighed, chopped into small pieces with a machete, and a representative subsample weighed. Flowerheads were removed from the remaining thistle foliage for subsequent autoclaving and the foliage discarded. The sub-sample was transported to the lab, oven dried at $64^{\circ} \mathrm{C}$ for five days and reweighed. The moisture content of the sub-sample and total plant fresh weight were used to calculate the dry weight of each thistle plant. Before thistle herbage was oven-dried, four randomly selected mature flowers from each of the five bare-ground plots were removed and stored in the $4^{\circ} \mathrm{C}$ chiller until they were dissected and the total number of seeds in each flowerhead counted.

\section{Statistical analyses}

Data were analysed using Genstat, 18th edition (VSN International 2015). All pasture growth data and autumn and winter thistle data were analysed as a Latin Square with row and column as random effects and treatment as the fixed effect.

By spring, there were no thistle plants present in the $12-\mathrm{cm}$ treatment and only one thistle (out of 75 thistle plants) in the $8-\mathrm{cm}$ treatment so these two treatments were omitted from the analysis, which used ANOVA with replicate as a random effect and treatment as the fixed effect. Thistle dry weight and flower, bud and seed numbers were log-transformed to equalise the variance to better meet the normality assumptions of the analysis. Actual means and standard errors are presented with the significance from the log analysis.

\section{Results}

\section{Herbage mass}

As expected, average herbage mass increased as sward height increased, before mowing and after mowing, in autumn, winter and spring $(\mathrm{P}<0.001$, Figure 2$)$.

\section{Thistle emergence and survival}

There was no emergence of thistle seedlings after June. The percentage of positions occupied (survival) was highest in the bare ground and 3-cm treatment (14\%), intermediate in the 6 - and $8-\mathrm{cm}$ treatments (averaging $7 \%)$ and lowest in the $12-\mathrm{cm}$ treatment $(3 \%, \mathrm{P}<0.001$, Figure 3).

By mid-September, all emerged thistle plants had died in the 12 -cm treatment, $\approx 90 \%$ of emerged plants died in the 6 - and $8-\mathrm{cm}$ treatments, but only $30 \%$ of emerged plants died in the bare ground and $3-\mathrm{cm}$ treatment. By the end of October, only one plant remained in the $8-\mathrm{cm}$ treatment and three plants in the 6-cm treatment (Fig. 3). With the onset of spring and reproductive development, thistle plants bolted. Thistle plants were tallest in the bare ground treatment $(\approx 130 \mathrm{~cm})$, intermediate in the 3 and $6-\mathrm{cm}$ treatments (averaging $25 \mathrm{~cm}$ ), and shortest in the 8 -cm treatment by early December $(1 \mathrm{~cm}, \mathrm{P}<0.001$, Figure 4a), with plant diameter following a similar trend $(\mathrm{P}<0.01$, Fig $4 \mathrm{~b})$. The one surviving thistle in the $8-\mathrm{cm}$ treatment remained short and spindly with minimal spread. Thistle plants in the $12-\mathrm{cm}$ treatment remained small throughout their brief lives. 

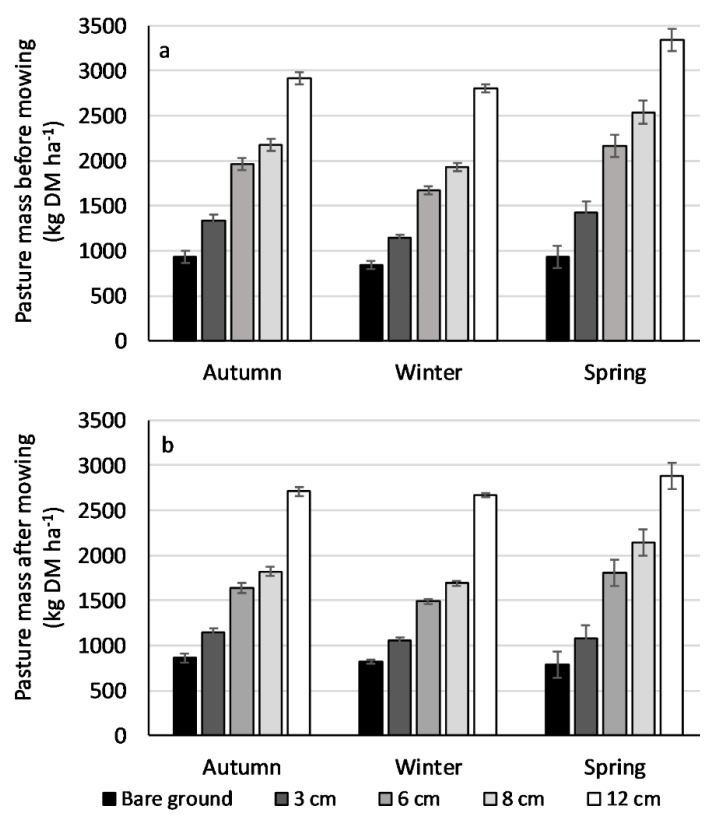

Figure 2 Average herbage mass before and after mowing swards maintained at heights of $0 \mathrm{~cm}$ (bare ground), $3 \mathrm{~cm}, 6 \mathrm{~cm}, 8 \mathrm{~cm}$ and $12 \mathrm{~cm}$, in autumn (March-May), winter (June-August) and spring (September-November) of 2019. Bars are standard errors of the mean. Data on herbage mass are presented in Table A1 of the Appendix.

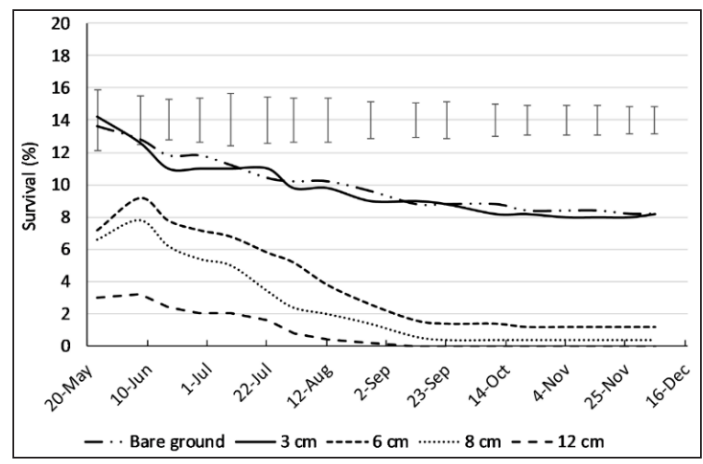

Figure 3 Percentage of sowing positions occupied by variegated thistle plants in swards maintained at heights of $0 \mathrm{~cm}$ (bare ground), $3 \mathrm{~cm}, 6 \mathrm{~cm}, 8 \mathrm{~cm}$ and $12 \mathrm{~cm}$ during 2019. Bars are standard errors of the mean.

\section{Thistle flowerhead and seed production}

Average thistle dry weight was over 30 -fold greater in the bare ground than in the $3-\mathrm{cm}$ treatment, and negligible in the $6-\mathrm{cm}$ treatment $\left(<0.1 \mathrm{~g} \mathrm{DW}\right.$ plant $^{-1}$, $\mathrm{P}=0.002$, Figure 5a). Data were insufficient to analyse in the $8-\mathrm{cm}$ treatment and all thistle plants had died in the $12-\mathrm{cm}$ treatment by early December.

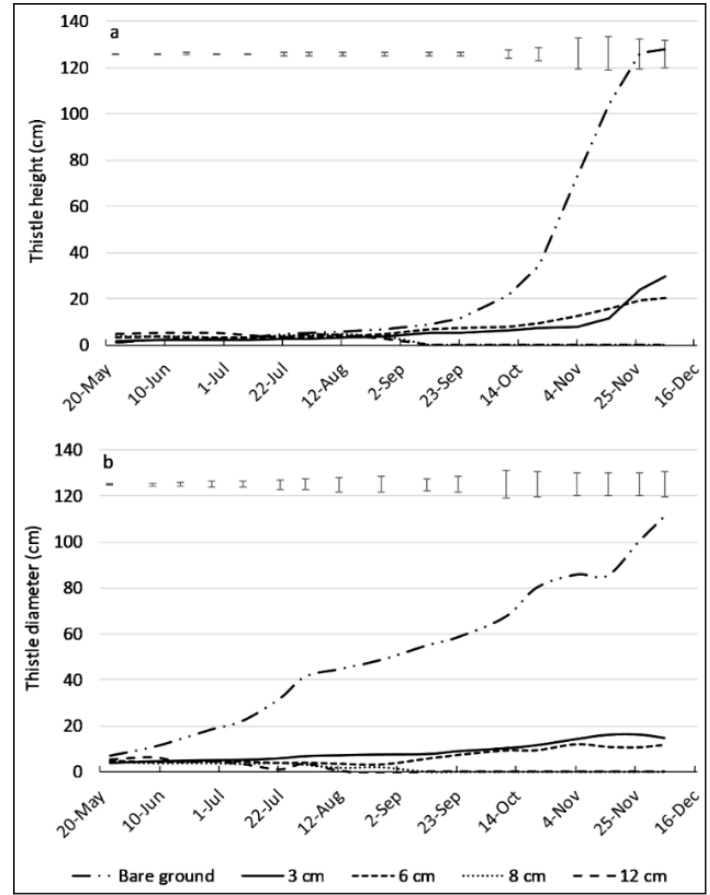

Figure 4 The average a) height; and b) rosette diameter of variegated thistle plants in swards maintained at heights of $0 \mathrm{~cm}$ (bare ground), $3 \mathrm{~cm}, 6 \mathrm{~cm}, 8 \mathrm{~cm}$ and $12 \mathrm{~cm}$. Bars are standard errors of the mean.

The most flowerheads ( 670 buds + flowers) per plant were produced in the bare-ground treatment, which was more than 35 -fold greater than the number of flowerheads produced in the $3-\mathrm{cm}$ and $6-\mathrm{cm}$ treatments (averaging 18 flowerheads plant ${ }^{-1}, \mathrm{P}<0.001$, Fig. 5b). No flowerheads were produced in the $8-\mathrm{cm}$ and $12-\mathrm{cm}$ treatments. Photographs of the plots in July, November and December are shown in Additional Online File 1.

Each plant produced an average of over 63,000 seeds in the bare ground treatment. Seed production in the $3-\mathrm{cm}$ and $6-\mathrm{cm}$ pasture height treatment was much lower and no seed was produced from the 8-and 12$\mathrm{cm}$ treatments $(\mathrm{P}<0.001$, Table 2$)$. As the size of the flowerhead increased in the bare ground treatment, seed production increased proportionally (Figure 6).

\section{Effect of sward height on photosynthetically active radiation}

There was a large decline in PAR as sward height increased (Figure 7a-e). The daily average PAR in the $3-\mathrm{cm}$ treatment was generally under half of that in the bare ground treatment. The levels of PAR fell rapidly in the $6-\mathrm{cm}, 8-\mathrm{cm}$ and $12-\mathrm{cm}$ treatments and from midJune onwards these treatments received negligible PAR. As the sward height increased the temperature range decreased, the maximum temperatures declined, 

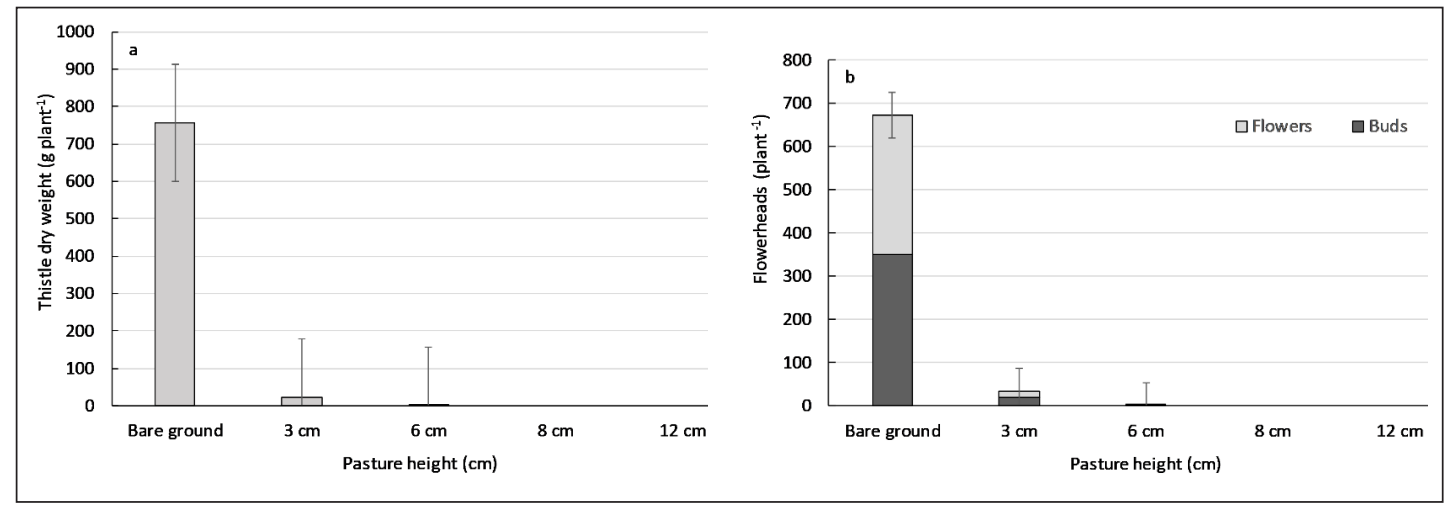

Figure 5 The average: a) dry weight per plant; and b) average number of buds (no purple petals visible) and flowers (purple petals visible) per plant of variegated thistle plants in swards maintained at heights of $0 \mathrm{~cm}$ (bare ground), $3 \mathrm{~cm}, 6 \mathrm{~cm}, 8 \mathrm{~cm}$ and $12 \mathrm{~cm}$. Bars are standard errors of the mean.

Table 2 The average number of seeds plant ${ }^{-1}$ produced from variegated thistle plants in swards maintained at heights of $0 \mathrm{~cm}$ (bare ground), $3 \mathrm{~cm}, 6 \mathrm{~cm}, 8 \mathrm{~cm}$ and $12 \mathrm{~cm}$. sed: standard error of difference of the mean.

\begin{tabular}{cccccccc}
\hline & Bare ground & $3 \mathbf{~ c m}$ & $6 \mathbf{c m}$ & $\mathbf{8 ~ c m}$ & $\mathbf{1 2} \mathbf{c m}$ & sed & P value \\
\hline Seeds plant $^{-1}$ & 63,200 & 3,200 & 100 & 0 & 0 & 9390 & $<0.001$ \\
\hline
\end{tabular}

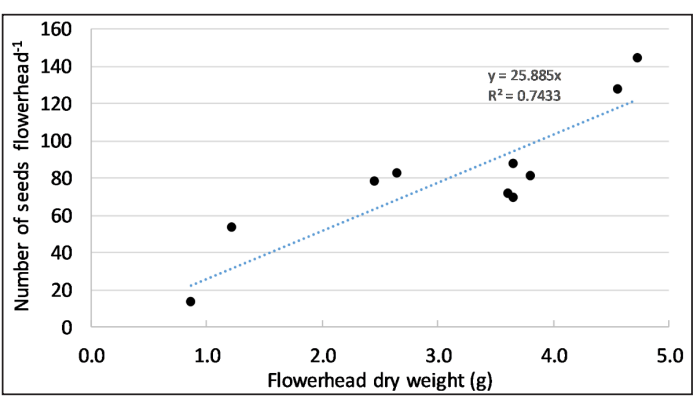

Figure 6 Relationship between the dry weight of variegated thistle flowerheads and the number of seeds flowerhead $^{-1}$ in the bare ground treatment, described by the equation: Number of seeds flowerhead $^{-1}=26^{*}$ flowerhead dry weight $(\mathrm{P}<0.05)$.

and the minimum temperatures increased. However, the average temperature remained relatively unaffected (Figure $7 \mathrm{f}-\mathrm{i}$ ).

\section{Soil moisture}

Soil moisture was higher in the bare ground than other treatments in April and May $(\mathrm{P}<0.01)$, and similar to all other treatments in June, July and December $(\mathrm{P}>0.05$, Figure 8). In September, soil moisture declined with increasing pasture height $(\mathrm{P}<0.05)$.

\section{Discussion}

The results from this trial open the possibility of adding another tool to help minimise the impact of an important invasive weed, variegated thistle, in the East Coast hill country environment, and other areas where this weed is an issue.

This trial demonstrated that manipulating herbage mass from autumn to late spring to increase pasture cover reduced the germination, growth, seed production and ultimately the survival of variegated thistle. All these factors will assist in reducing the establishment of new thistle plants in future autumn periods provided that there is little or no bare ground.

The ability of farmers to manipulate pasture covers from the late summer/autumn period may differ from year to year depending on summer rainfall and pasture supply. If farmers can maintain a post-grazing herbage mass of at least $1600 \mathrm{~kg} \mathrm{DM} \mathrm{ha}^{-1}$ i.e. 6-cm pasture height, for a period of 4 months then this practice will suppress thistle germination, survival, growth and seed production. While maintaining this level of postgrazing pasture mass may be difficult, it is clear that at least maintaining a herbage mass of around $1100 \mathrm{~kg} \mathrm{DM}$ $\mathrm{ha}^{-1}$, i.e. $3-\mathrm{cm}$ pasture height, for 5 months will severely reduce the regeneration of variegated thistle. Although most thistle plants in the $3-\mathrm{cm}$ treatment survived from emergence until early summer, they remained small (with little impact on the surrounding pasture) and produced only a few small flowerheads with low seed numbers. Most variegated thistle populations re-establish in autumn from seed produced in the previous spring (James \& Tozer 2018) so reducing seed production in one year will severely limit variegated 

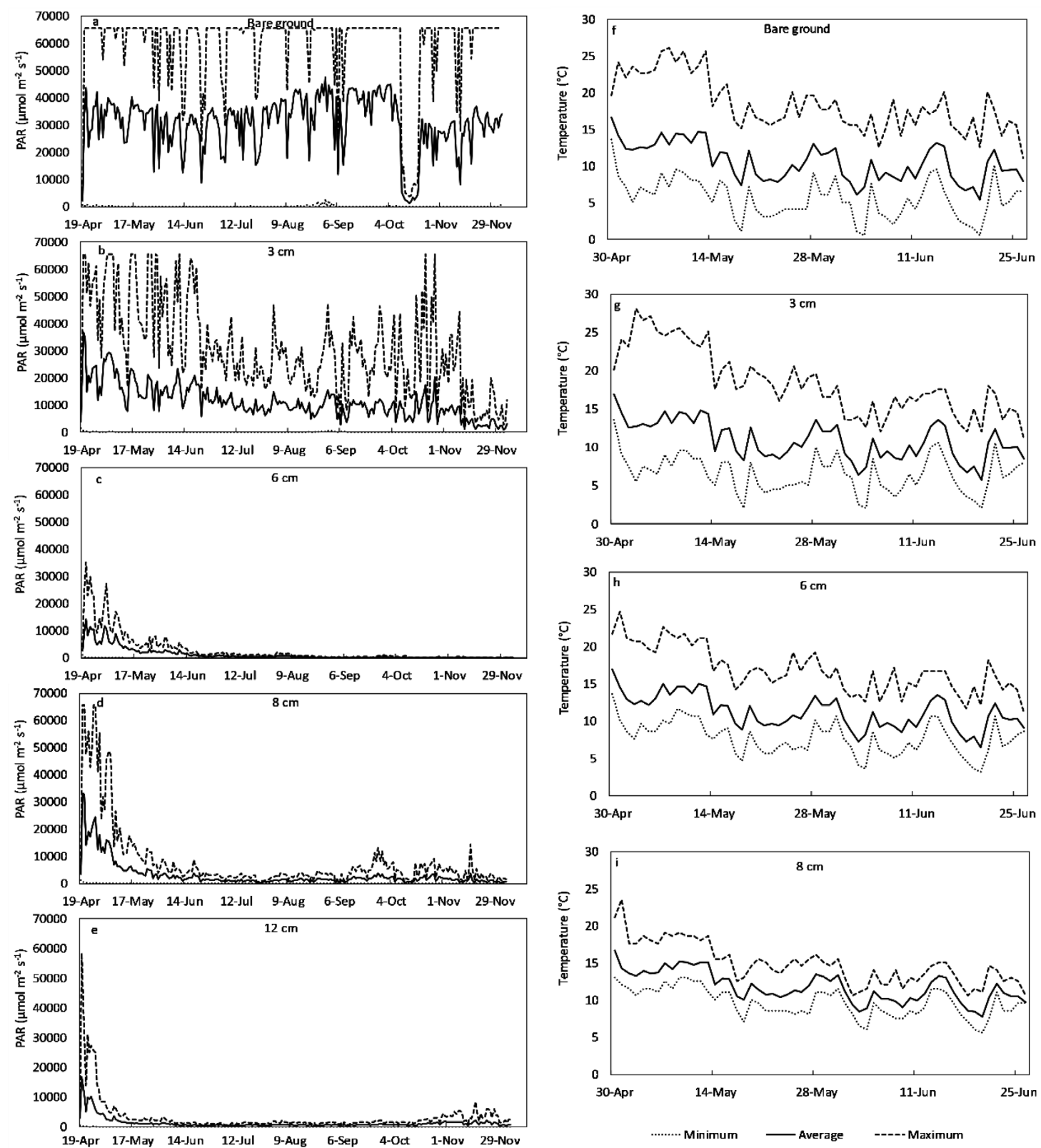

Figure 7 Data for: (a-e) daily maximum, average and minimum photosynthetically active radiation (PAR; $\left.\mu \mathrm{mol} \mathrm{m} \mathrm{m}^{-2} \mathrm{~s}^{-1}\right)$ at the soil surface 19 April $-5 \mathrm{Dec}$; and $(\mathrm{f}-\mathrm{i})$ temperature $\left({ }^{\circ} \mathrm{C}\right)$ of the topsoil $(0-2.5 \mathrm{~cm}$ depth), in swards maintained at $0 \mathrm{~cm}$ (bare ground), $3 \mathrm{~cm}, 6 \mathrm{~cm}$ and $8 \mathrm{~cm}$. No data could be obtained from the probe in the 12-cm treatment.

thistle population growth and its negative impact on livestock production in successive years.

It is unlikely that a farmer could maintain pasture covers at sufficient levels to suppress variegated thistle over the whole of the farm or on areas such as stock camps or stony northern ridges, or other areas affected by variegated thistle in one year, but selected areas could be targeted in successive years. The grazing interval could be lengthened over as many weeks as possible in the areas targeted to allow a build-up of pasture cover. This period could be up to 8 weeks for East Coast pastures. In addition to enabling the accumulation of herbage from existing plants, lengthening the grazing interval in autumn has the added advantage of allowing perennial grasses and other desirable plants in the seedbank to colonise gaps, thereby reducing 


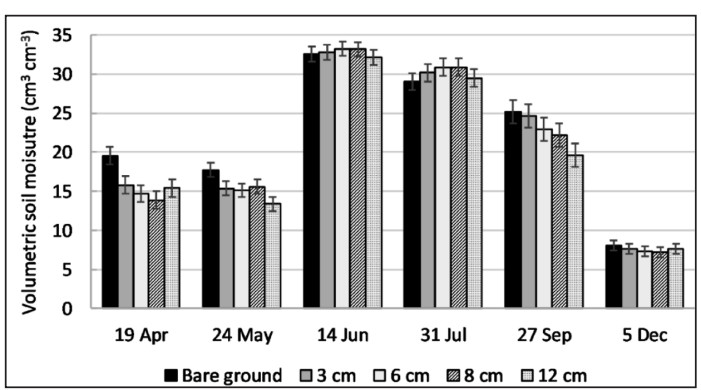

Figure $8 \quad$ Volumetric soil moisture content $\left(\mathrm{cm}^{3}\right.$ of water per $\mathrm{cm}^{3}$ of soil) in swards maintained at heights of $0 \mathrm{~cm}$ (bare ground), $3 \mathrm{~cm}, 6 \mathrm{~cm}, 8 \mathrm{~cm}$ and $12 \mathrm{~cm}$. Bars are standard errors of the mean.

the opportunity for variegated thistle establishment (Tozer et al. 2018). In some cases, herbicide may be required to remove the thistle population after which grazing management practices can be used to focus on increasing cover in areas susceptible to ingress of variegated thistle (Tozer et al. 2018). The predominant factor associated with suppression of thistle plants is clearly the competition for light (as shown by the reduction in average photosynthetic radiation as sward height increased). This result is consistent with the findings of Montemurro et al. (2007) that more variegated thistle seed germinated in the light than in the dark (66 vs 49\%) and that germination was suppressed by accumulation of grass litter. In addition, Pook (1983) found that, while variegated thistle survival was relatively unaffected by shading in a glasshouse study, its growth was supressed in proportion to the level of shade in winter. Further, in that study, a $70 \%$ reduction in daylight resulted in an approximately $80 \%$ reduction in shoot and root mass (Pook 1983). Given this impact, it might be possible that a shorter period (i.e. up to 2 months) of maintaining higher pasture covers will be equally as effective at controlling variegated thistle to an acceptable level.

The effects of different sward heights on topsoil temperature and moisture status were small and did not account for the suppression of thistle production demonstrated by the result of this experiment. Soil moisture was measured to a depth of $12.0 \mathrm{~cm}$; the effect of sward height on soil moisture at deeper levels and its impact on thistle growth is unknown. It is feasible that deep-rooted perennial species would compete with variegated thistle for moisture and nutrients at depth and reduce thistle growth and survival (Pook 1983).

\section{Conclusion}

In combination with other methods such as judicious herbicide use, increasing resident pasture cover in autumn and early winter could be a cost-effective strategy for reducing establishment of variegated thistle populations. Bare areas such as stock camps may be difficult to revegetate. However, removal of bare areas in more productive parts of the landscape by increasing the herbage present can reduce thistle presence and impact where it can be particularly damaging to pasture production. Forward planning would be required to focus on specific areas of the farm and specific paddocks to allow as much accumulation of pasture for as long as possible.

\section{ACKNOWLEDGEMENTS}

Thanks to MBIE C10X1806, AgResearch SSIF and Ravensdown for financing this trial, the staff of Wi Pere for their assistance in establishing the site and providing suggestions as to how results can be applied on-farm, the members of the Ravensdown/AgResearch co-innovation team: Mike Manning, Sue Quilter (Ravensdown); Mike Dodd, Robyn Dynes and Trevor James (AgResearch) for constructive discussion, and Mike Cripps and Trevor James for their editorial expertise in reviewing the paper.

\section{SUPPLEMENTARY MATERIAL}

Additional Online File 1: Plate showing photographs from three different dates of the field site in which variegated thistle seeds were hand-sown into swards. https://www.nzgajournal.org.nz/index.php/JoNZG/ article/view/439

\section{REFERENCES}

BourdôtGW, Fowler SV, Edwards GR, Kriticos DJ, Kean JM, Rahman A, Parsons AJ. 2007. Pastoral weeds in New Zealand: status and potential solutions. New Zealand Journal of Agricultural Research 50: 139161. https://doi.org/10.1080/00288230709510288

Bourdôt GW, Leathwick DM, Hurrell GA, Saville DJ. 2015. Competitive exclusion of Cirsium arvense in pasture: a simulated neighbour grazing-height experiment. New Zealand Journal of Agricultural Research 58: 1-12. https://doi.org/10.1080/0028823 3.2014.941507

Finger R. 2018. Take a holistic view when making pesticide policies stricter. Nature 556: 174. https:// doi.org/10.1038/d41586-018-04166-5

Greenfield R, Tozer K, Zobel G, Cameron C, North E. 2019. The impact of cutting prior to goat grazing on variegated thistle (Silybum marianum). New Zealand Plant Protection 72: 158-165. https://doi. org/10.30843/nzpp.2019.72.315

Harrington KC, Beskow WB, Hodgson J. 2011. Recovery and viability of seeds ingested by goats. New Zealand Plant Protection 64: 75-80. https://doi. org/10.30843/nzpp.2011.64.5965

Heap I. 2014. Global perspective of herbicide-resistant 
weeds. Pest Management Science 70: 1306-1315. https://doi.org/10.1002/ps.3696

James TK, Tozer KN. 2018. Soil seed bank under variegated thistle does not explain thistle dominance. New Zealand Plant Protection 71: 51-56. https://doi. org/10.30843/nzpp.2018.71.181

Khan MA, Blackshaw RE, Marwat KB. 2009. Biology of milk thistle (Silybum marianum) and the management options for growers in north-western Pakistan. Weed Biology and Management 9: 99-105. https://doi.org/10.1111/j.1445-6664.2009.00326.x

Michael PW. 1968. Perennial and annual pasture species in the control of Silybum marianum. Australian Journal of Experimental Agriculture 8: 101-105. https://doi.org/10.1071/EA9680101

Montemurro P, Fracchiolla M, Lonigro A. 2007. Effects of some environmental factors on seed germination and spreading potentials of Silybum marianum Gaertner. Italian Journal of Agronomy 2: 315-320. https://doi.org/10.4081/ija.2007.315

Phung HT, Popay AI. 1981. Effect of pasture cover on the germination of certain weed seeds. Proceedings of the NZ Weed and Pest Control Conference 34: 111-
113. https://doi.org/10.30843/nzpp.1981.34.10605

Pook EW. 1983. The effect of shade on the growth of variegated thistle (Silybum marianum L.) and cotton thistle (Onopordum sp.). Weed Research 23: 11-17. https://doi.org/10.1111/j.1365-3180.1983.tb00515.x

Scholtens M, Smith R, Lopez-Lozano S, LopezVillalobos N, Burt D, Harper L, Tuohy M, Thomas D, Carr A, Gray D. 2017. The current state of the New Zealand goat industry. New Zealand Society of Animal Production: 164-168.

Stevens DR, Tozer KN, Rhodes T, Zydenbos SM, Dynes RA, Manning MJ, Roberts AH, White M, Metherell A. 2019. Farm systems analysis of two thistles of differing seasonal pasture growth impacts in North Island hill country. Journal of New Zealand Grasslands 81: 149-158. https://doi.org/10.33584/ jnzg.2019.81.411

Tozer KN, Greenfield RM, Dodd MB, James TK, Cameron CA. 2018. Controlling variegated thistle in East Coast North Island hill-country. Journal of New Zealand Grasslands 80: 225-234. https://doi. org/10.33584/jnzg.2018.80.326

\section{APPENDIX}

Table A1 Average herbage mass before and after mowing swards maintained at heights of $0 \mathrm{~cm}$ (bare ground), $3 \mathrm{~cm}, 6 \mathrm{~cm}, 8 \mathrm{~cm}$ and $12 \mathrm{~cm}$, in autumn (March-May), winter (June-August) and spring (September-November). sed: standard error of the mean.

\begin{tabular}{|c|c|c|c|c|c|c|c|c|}
\hline \multirow[t]{2}{*}{ Timing } & \multirow[t]{2}{*}{ Season } & \multicolumn{5}{|c|}{ Average Pasture mass (kg ha-1) } & \multirow[t]{2}{*}{ sed } & \multirow[t]{2}{*}{$P$ value } \\
\hline & & Bare ground & $3 \mathrm{~cm}$ & $6 \mathrm{~cm}$ & $8 \mathrm{~cm}$ & $12 \mathrm{~cm}$ & & \\
\hline \multirow[t]{3}{*}{ Pre-mowing } & Autumn & 930 & 1340 & 1960 & 2180 & 2920 & 67 & $<0.001$ \\
\hline & Winter & 840 & 1140 & 1670 & 1930 & 2800 & 43 & $<0.001$ \\
\hline & Spring & 930 & 1420 & 2160 & 2540 & 3340 & 124 & $<0.001$ \\
\hline \multirow[t]{3}{*}{ Post-mowing } & Autumn & 860 & 1140 & 1640 & 1820 & 2710 & 53 & $<0.001$ \\
\hline & Winter & 820 & 1060 & 1490 & 1690 & 2670 & 26 & $<0.001$ \\
\hline & Spring & 790 & 1080 & 1810 & 2140 & 2880 & 146 & $<0.001$ \\
\hline
\end{tabular}

